Keywords:

Base flow

Streamflow regime

Springs

Historic:

Recebido 21/06/201 I

Aceito 04/10/2013

Palavras chave:

Escoamento base

Regime de escoamento

Nascentes

Correspondence: alissonso@hotmail.com

DOI: | $0.1590 / 0|04776020| 42003$ |268
Alisson Souza de Oliveira', Antônio Marciano da Silva', Carlos Rogério de Mello', Geovane Junqueira Alves'

\section{STREAM FLOW REGIME OF SPRINGS IN THE MANTIQUEIRA MOUNTAIN RANGE REGION, MINAS GERAIS STATE}

ABSTRACT: The stream flow regime of four springs located in the Mantiqueira Mountain Range region (MG) was evaluated and correlated to the respective recharge area, relief characteristics, land cover and physical and hydrologic soil characteristics. The streamflow regime was characterized by monitoring of discharges, calculating the surface runoff and specific discharge and by modeling the discharge over the recession period using the Maillet method. As all recharge areas have similar relief the effect of it on the streamflow was not possible to identify. Analysis included determining the effect of drainage area size, soil characteristics and land cover on the indicators of the streamflow regime. Size of the recharge area had a positive influence on the indicators mean discharge and surface runoff volume and on the regulation of the streamflow regime (springs L4 and LI). The spring under the smallest area of influence provided the worst results for the above mentioned indicators (spring L3). The effect of forest cover (natural and planted), associated with soil characteristics, was evidenced by the indicators surface runoff (in depth) and specific yield, both independent of the recharge area size (springs L4 and L2). The interaction of area size, soil characteristics and forest cover (natural and planted) provided the best results for all indicators of streamflow regime in the springs studied in the Mantiqueira Mountain Range (spring L4).

\section{REGIME DO ESCOAMENTO EM NASCENTES NA REGIÃO SERRA DA MANTIQUEIRA, MG}

RESUMO: O regime do escoamento de quatro nascentes inseridas na região da Serra da Mantiqueira - MG, foi avaliado em associação à área de recarga, ao relevo, à cobertura vegetal e aos atributos físico-hídricos do solo. Para tanto, caracterizou-se o regime de escoamento pelo monitoramento das vazões, pelo cálculo do deflúvio e da vazão específica e pela modelagem da vazão no período de depleção segundo "Maillet". Todas as áreas apresentaram relevos semelhantes, dificultando evidenciar o efeito dos mesmos. Foi evidenciado o efeito do porte da área de drenagem, dos atributos do solo considerados e da cobertura vegetal nos indicadores do regime de escoamento das nascentes. $O$ porte da área de recarga evidenciou sua influência positiva sobre os indicadores vazão média e deflúvio em volume e sobre o grau de regularização do regime de escoamento (nascentes L4 e LI), a nascente sob a menor área de influência apresentou os piores valores para esses indicadores (nascente L3). O efeito da cobertura vegetal do solo na forma de mata (nativa e plantada), associado aos dos atributos do solo, foi evidenciado pelos indicadores deflúvio em lâmina e rendimento específico que independem da área de recarga (nascentes L4 e L2). A interação porte de área, atributos do solo e cobertura vegetal sob mata (nativa e plantada), gerou os melhores valores para todos os indicadores do regime escoamento das nascentes (nascente L4).

' Universidade Federal de Lavras - Lavras, Minas Gerais, Brazil 


\section{INTRODUCTION}

The quality and avalaibility of water emerging from springs may be affected by several factors but mainly by physical and hydrological soil characteristics, land cover and slope, particularly in recharge areas, as they influence both water storage and the streamflow regime of catchments (PINHEIRO et al., 20I I; PINTO et al., 2004). According to Cortines (2008), recharge areas or hydrogenetic zones are sectors of a catchment which may be divided into capture areas, transfer areas and outcrop areas. In capture areas there is a prevalence of infiltration while in transfer areas there is a prevalence of actual surface runoff, and outcrop areas are those in which the springs emerge.

Pires and Santos (1995) argue that absence of a vegetation cover leads to a reduction both in the amount of water infiltratation in the soil and in groundwater storage, not only influencing the discharge pattern and volume of flow but also contributing to increase soil erosion and siltation in watercourses.

Regarding soils aspects, one should consider the role of vegetation in some of its physical and hydrologic characteristics, consequently reflecting in the water dynamic. In a study about the influence of different types of vegetation at watersheds in Pará state, Schuler (2003) observed a reduction in hydraulic conductivity and in soil porosity under pastureland conditions, in comparison with forestland, leading to an increase in surface runoff.

A pedologic survey is important in such context in order to identify and group soils with similar hydrology functionality. Therefore, the characterization of the physical environment in which catchments are inserted, especially the recharge areas of springs, in an attempt to identify critical aspects relating to water maintenance, are preconditions for successfully planning for water flow generation and conservation.

Thus, the aim of this study was to correlate the streamflow regime of four springs located in the Mantiqueira Mountain Range region (MG) with respective recharge areas, relief, land cover and physical and hydrologic characteristics of the soils.

\section{MATERIAL AND METHODS}

\section{Spring characterization and its respective environment}

The springs were termed LI (UTM coordinates 554I98.1 I 9 W, 7553658.845 S), L2 (UTM coordinates 55399I.300 W, 755354I.I72 S), L3 (UTM coordinates $554996.865 \mathrm{~W}, 75526 \mid 4.055 \mathrm{~S}$ ) and L4 (UTM coordinates $555503.214 \mathrm{~W}, 7552521.344 \mathrm{~S})$ and are located in the Lavrinha Creek Watershed, in Mantiqueira Mountain Range region, MG (Figure I), at altitudes that range from I,I 44 to I,739, covering a drainage area of $6.87 \mathrm{~km}^{2}$ and regarded as a headwater watershed (JUNQUEIRA JÚNIOR, 2006). Yanagi (2008) preliminarily classified the local climate as $\mathrm{ArB}_{2}{ }_{2} \mathrm{a}^{\prime}$, with average temperatures of $19^{\circ} \mathrm{C}$ in hottest months and $11^{\circ} \mathrm{C}$ in coldest months, with occurrence of frosts.

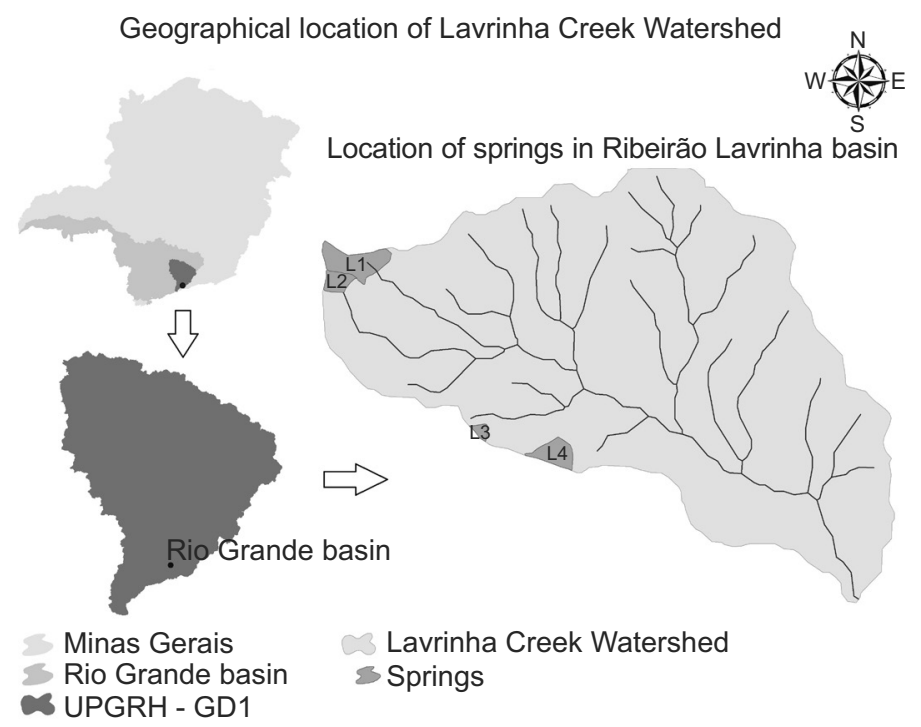

FIGURE I Geographical location of Lavrinha Creek Watershed and of the springs studied, UPGRH- GDI and Minas Gerais State. FIGURA I Localização da bacia hidrográfica do ribeirão Lavrinha e das nascentes estudadas, da UPGRH- GDI, e do Estado de Minas Gerais. 
The contributing areas studied are located in the proximities of the topographic water divide, however, their size and relief make it difficult to identify the capture area. Therefore, only the transfer and outcrop areas were defined. Because the springs have a perennial flow regime and thus denote hydrologic sustainability, the recharge areas were demarcated taking into account the ridgeline divides starting from the control section of each spring, using the digital elevation model (SILVA, 2009).

The local soils are predominantly Cambisol CX A with weak horizon and very rugged terrain (LI and L2), and Cambisol CXA with moderate horizon and very rugged terrain ( $L 3$ and $L 4$, Figure 2 ).

Table I provides information about recharge areas, relief and land cover, as well as physical and hydrologic soil characteristics, which were obtained by Junqueira Júnior (2006) and Silva (2009). Springs LI and $L 4$ boast the largest areas, a factor potentially influencing their streamflow regime. The relief in the recharge area of each spring was determined using the digital elevation model, which revealed a predominance of very rugged terrain in all areas and average slopes typical of this relief class. Thus, this factor indicates that relief should not be used here as a differentiating factor to define the streamflow regime of the springs.

Regarding land use, there is a predominance of pastureland in springs LI $(92.9 \%)$ and L3 (99\%), of native forest in spring $\mathrm{L} 2$ and of combined native/planted forest (eucalyptus) in spring L4 $(54.6 \%)$ as its area is most commonly used for pastureland.

The physical and hydrologic soil characteristics assessed was total pore volume (VTP), defined as being the porous space of the volumetric fraction of soil, which is the space where dynamic processes of the soil solution and gases occur (HILLEL, 197I). The soil in spring L3 had the most porosity, including the drainable portion (macropores). Organic matter is an important factor for the water infiltration process, as it directly influences the soil structure, consequently affecting soil porosity and pore distribution while increasing the water retention and storage capacity. Drainable porosity $(\mu)$ determines the participation of macropores, estimated as the difference between VTP and $\theta_{c c}$ (moisture content at field capacity). Finally, the saturated hydraulic

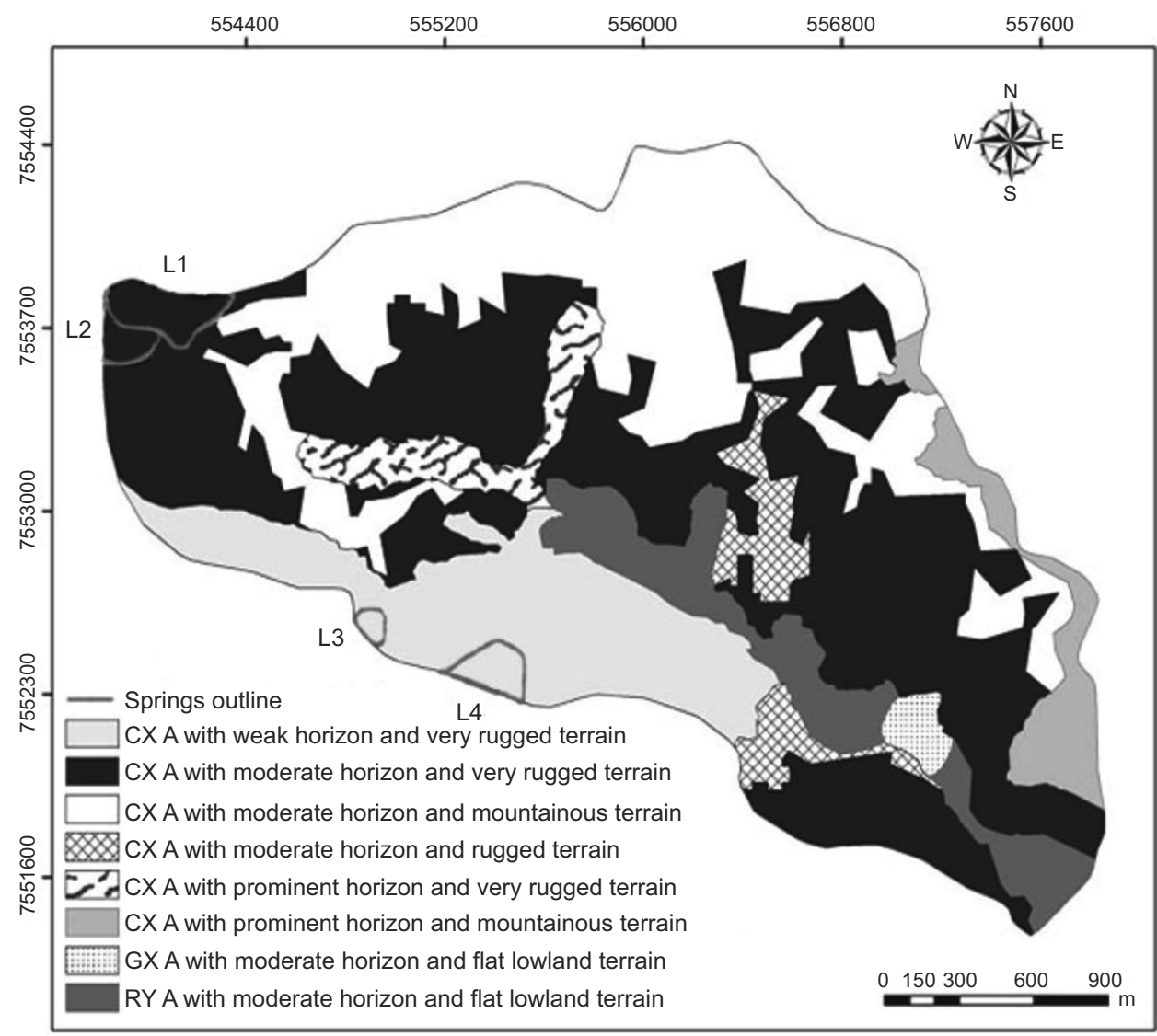

FIGURE 2 Location of springs and spatial distribution of soil units in Ribeirão Lavrinha drainage basin (MENEZES et al., 2009).

FIGURA 2 Localização das nascentes e distribuição espacial das unidades pedológicas na Bacia do Ribeirão Lavrinha (MENEZES et al., 2009). 
TABLE I Distribution of soil classes, predominant land cover and physical and hydrological soils characteristics in the recharge area.

TABELA I Distribuição das classes de solos, uso predominante e atributos físico-hídricos do solo na área de recarga das nascentes.

\begin{tabular}{|c|c|c|c|c|}
\hline & \multicolumn{4}{|c|}{ Springs } \\
\hline & LI & L2 & L3 & L4 \\
\hline Soil Class* & \multicolumn{2}{|c|}{$\begin{array}{c}\text { Cambisol CX A } \\
\text { weak horizon, } \\
\text { very rugged } \\
\text { terrain }\end{array}$} & \multicolumn{2}{|c|}{$\begin{array}{c}\text { Cambisol CXA } \\
\text { moderate } \\
\text { horizon, very } \\
\text { rugged terrain }\end{array}$} \\
\hline Recharge Area (ha) ${ }^{*}$ & 7.24 & 2.43 & 0.87 & 5.14 \\
\hline Relief Class ** & \multicolumn{4}{|c|}{$\begin{array}{l}\text { Distribution of relief classes per } \\
\text { spring } \%\end{array}$} \\
\hline Very mountainous (>75\%) & 0.1 & 0.0 & 11.6 & 2.6 \\
\hline Mountainous (45-75\%) & 10.9 & 24 & 23.8 & 20.8 \\
\hline Very rugged (20-45 \%) & 67.2 & 57.3 & 29.9 & 62.0 \\
\hline Rugged (8-20\%) & 19.5 & 17.2 & 28.9 & 13.0 \\
\hline Slightly rugged (3-8\%) & 1.6 & 1.5 & 5.3 & 1.4 \\
\hline Flat $(0-3 \%)$ & 0.7 & 0.0 & 0.5 & 0.2 \\
\hline Average slope (\%) & 28.7 & 33.9 & 38.5 & 37.1 \\
\hline \multicolumn{5}{|l|}{ Predominant Use (\%) ${ }^{* *}$} \\
\hline Pasture & 92.9 & 32.9 & 99 & 45.4 \\
\hline Ferns & 6.9 & 0 & 0 & 0 \\
\hline Forest & 0.2 & 67.1 & 1 & 31.4 \\
\hline Eucalyptus & 0 & 0 & 0 & 23.2 \\
\hline \multicolumn{5}{|c|}{ Physical and Hydrological Characteristics *** } \\
\hline VTP (\%) & 52 & 55 & 57 & 54 \\
\hline$\mu(\%)$ & 31 & 30 & 34 & 32 \\
\hline $\mathrm{K}_{0}\left(\mathrm{~m} \cdot \mathrm{day}^{-1}\right)$ & 0.4 & 0.3 & 1.1 & 1.05 \\
\hline Organic matter (\%) & 3.6 & 3.6 & 5.8 & 4.6 \\
\hline
\end{tabular}

Sources: "Menezes et al. (2009); " Silva (2009); Junqueira Júnior (2006).

conductivity $\left(\mathrm{K}_{0}\right)$ of soils determines its maximum capacity to cause water to move through pore spaces. All these physical and hydrological characteristics were determined based on a systematic field survey, and the results of which were analyzed using Geostatistics (JUNQUEIRA JÚNIOR, 2006).

\section{Discharge monitoring and flow regime characterization}

Discharges were monitored by a WSC flow measurement flume (Figure 3) on a fortnightly time step between October 2009 and October 2010. That measurements correspond to the base flow, that is, there was no contribution from direct surface runoff. Precipitation was also quantified over the study period using a rain gauge installed in the recharge area of spring LI.

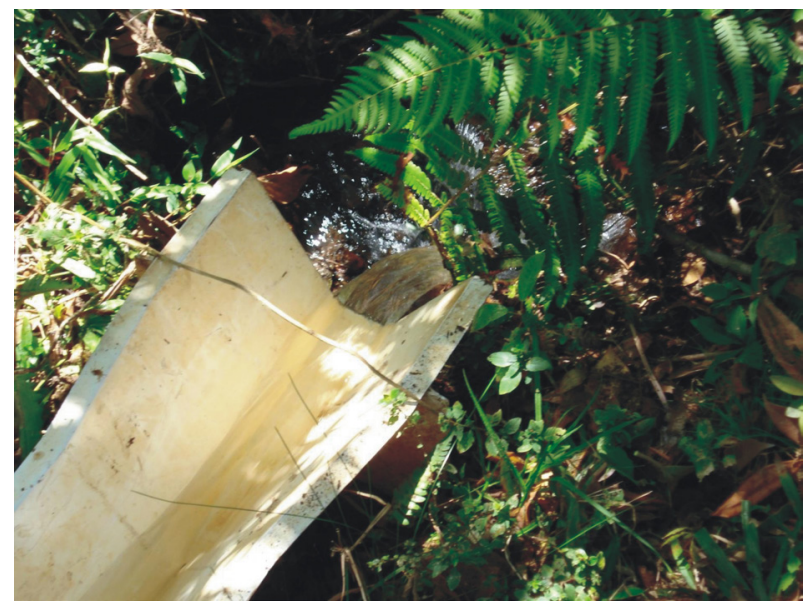

FIGURE 3 WSC flow measurement Flume.

FIGURA 3 Medidor de vazão WSC Flume.

The streamflow generated by each spring over the study period was estimated by numerically integrating discharge data and also calculating the specific discharge of each spring along with their average runoff.

For each spring, over the period April to September (dry period), a model was parametrized by the Newton Raphson method to estimate discharge depletion (equation I) according to the Maillet formula (CASTANY, 1967), where $Q_{t}=$ is the spring discharge over time $\mathrm{t}\left(\mathrm{m}^{3} \cdot \mathrm{s}^{-1}\right) ; \alpha=$ is the coefficient of discharge depletion $\left(\right.$ day $\left.^{-1}\right)$, reflecting the rate of discharge variation over time. This index is mainly dependent on geology, soil type and geomorphology (COSTA; BACELLAR, 2010; USAE, 1999) and thus may vary according to each drainage area; $\mathrm{t}_{0}=$ é is the Julian day (DJ - computed from 0I/Jan/2009), corresponding to the start of the depleting groundwater period and $t$ is the Julian day for which discharge is estimated, with $t \geq t_{0}$. For purposes of comparing discharge in the springs of interest, the start of the depletion period was defined as $D J=79$, corresponding to 20/March/2009.

$$
Q_{t}=Q_{t} \cdot e^{-\alpha \cdot(t-t)}
$$

\section{RESULTS AND DISCUSSION}

As Table I illustrates, the reliefs of the recharge areas could be classified in the same class, which reduces the likeliness of relief being a differentiating factor of flow regime in the springs. Springs $L I$ and $L 2$ both presented the same soil class with similar physical and hydrologic characteristics. This same condition can be observed for L3 and L4 springs, thus, there is no need to promote discussions between these two spring pairs over these factors. 


\section{Values of annual flow}

In Table 2, it is presented values of annual base runoff, its breakdown for the recharge and recession period, mean annual discharge and mean annual specific yield (RE), for each spring.

Based on the data presented in Table 2, the influence the recharge area has on the total volume of flow (runoff) and on the corresponding mean annual discharge as well. The larger the recharge area the greater the runoff and the mean annual discharge, except in spring L4, which though with the second largest recharge area, provided higher values for these two parameters. This fact is probably due to an interaction of two factors, namely the physical and hydrological soils characteristics strongly favoring infiltration and due to most of its recharge area occupied by forestland (native and planted) (Table I). Along this line of reasoning, spring L3, which has similar physical and hydrological soils characteristics to spring $L 4$, has the smallest drainage area and $99 \%$ of it is pastureland. The interaction of these factors reduces the opportunity time for infiltration and consequently the groundwater recharge, resulting in the lowest values for these indicators. $\mathrm{LI}$ has the largest recharge area and its soil characteristics are less favorable to the infiltration process, combined with a land cover that is predominantly formed by pastureland, which intensifies its unfavorable condition in relation to spring L4.

From the values of runoff (in depth) and mean annual specific yield which are unaffected by the size of the recharge area, it was found that spring L4 had the highest values, due to the same reasons discussed previously. Spring L2 came next and, compared to spring $\mathrm{LI}$, whose differentiating factor is the land cover $(67.1 \%$ of native forest in L2 against $0.2 \%$ in LI, Table I), it was found that the same determining factor contributed to this pattern. A breakdown of runoff revealed that spring L4 had greater capacity for natural regulation, since its recharge/depletion ratio was close to $50 \%$, followed by springs $L 1, L 2$ and $L 3$, in the same descending order of the recharge areas. Again, the size of the recharge area and the interaction of soil characteristics with the forest cover influenced in such way as to facilitate the recharge process.

Similar results were found by Menezes et al. (2009) in a study exploring two springs in the Lavrinha Creek Watershed, under the same soil type. These authors observed that the spring whose discharge area was under Atlantic Forest was more stable throughout the year than the other spring under pastureland. Pinto et al. (2004) found higher discharge results in springs whose soils were under native forest domain, compared to pastureland. According to these authors, native forest favored better rainwater infiltration into the soil, promoting, consequently, groundwater recharge and replenishing springs while reducing the amount of water directly drained into riverbeds.

The above discussions lead to the inference that forest environment favors the infiltration and groundwater recharge process, regardless of the physical and hydrologic soils characteristics, similarly to results found by Pinheiro et al. (2009). These authors reported that the infiltration capacity of soils reforested with Pinus is similar to that of soils under native forest but better than that of soils under pastureland. Infiltration in forested areas tends to be intensified compared to bare land or agricultural land (BRANDÃO et al., 2006) due to the perennial vegetation cover in such environments continually recovering the ground surface with litter (ANTONELI; THOMAZ, 2009).

\section{Recession discharge rates modeling}

Figure 4 and Table 3 present the hydrographs that show the discharge recession with respective equations, $Q_{\mathrm{t}} / \mathrm{Qt}_{0}$ ratio and estimated runoff rate for each spring. Regarding the discharge at the start of the recession period $\left(\mathrm{Qt}_{0}\right)$ which reflects the influence of the

TABLE 2 Values of annual flow for each spring.

TABELA 2 Valores característicos do escoamento anual das nascentes.

\begin{tabular}{|c|c|c|c|c|c|c|}
\hline \multirow{3}{*}{ Springs } & \multicolumn{4}{|c|}{ Base runoff (Db) } & \multirow{3}{*}{$\frac{\mathrm{Q}_{\text {annual mean }}}{\left(\mid \cdot \mathrm{s}^{-1}\right)}$} & \multirow{3}{*}{$\frac{\mathrm{RE}_{\text {annual mean }}}{\left(\mathrm{I} \cdot \mathrm{s}^{-1} \cdot \mathrm{ha}^{-1}\right)}$} \\
\hline & \multicolumn{2}{|c|}{ Annual } & \multirow{2}{*}{$\frac{\text { Recharge }}{(\mathrm{mm})}$} & \multirow{2}{*}{$\frac{\text { Depletion }}{(\mathrm{mm})}$} & & \\
\hline & $\left(\right.$ dam $\left.^{3}\right)$ & $(\mathrm{mm})$ & & & & \\
\hline LI & 37.261 & 514.9 & 309.6 & 205.3 & 1.21 & 0.17 \\
\hline L2 & 15.283 & 630.0 & 423.8 & 206.2 & 0.49 & 0.20 \\
\hline L3 & 1.656 & 190.8 & 130.2 & 61.1 & 0.05 & 0.06 \\
\hline L4 & 55.310 & 1075.3 & 541.4 & 534.5 & 1.79 & 0.35 \\
\hline
\end{tabular}




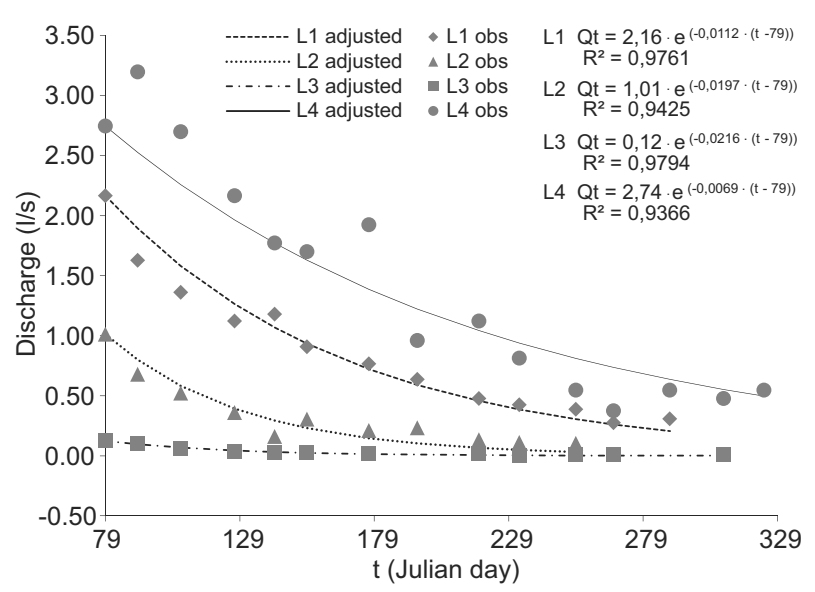

FIGURE 4 Discharge recession curve for the four springs.

FIGURA 4 Curva de depleção das vazões das quatro nascentes estudadas.

TABLE 3 Parameters of the recession period.

TABELA 3 Parâmetros característicos do período de depleção.

\begin{tabular}{cccccc}
\hline Spring & $\begin{array}{c}\alpha \\
\left(\text { day }^{-1}\right)\end{array}$ & $\mathrm{Q}_{\mathrm{t}(20 / 03)}$ & $\mathrm{Q}_{\mathrm{t}(16 / 10)}$ & $\left(\mathrm{Q}_{\mathrm{t}} / \mathrm{Q}_{\mathrm{t} 0}\right)$ & $\begin{array}{c}\text { Estimated } \\
\text { runoff }(\mathrm{mm})\end{array}$ \\
\hline $\mathrm{LI}$ & 0.0112 & 2.16 & 0.300 & 0.139 & 208.6 \\
$\mathrm{~L} 2$ & 0.0197 & 1.01 & 0.016 & 0.016 & 179.5 \\
$\mathrm{~L} 3$ & 0.0216 & 0.12 & 0.001 & 0.008 & 54.6 \\
$\mathrm{~L} 4$ & 0.0069 & 2.74 & 0.630 & 0.230 & 510.8 \\
\hline
\end{tabular}

preceding recharge period, it was noted that the values correlate directly with the recharge areas, excepting spring L4 which, as has been discussed previously, showed the highest recharge capacity as a function of the interaction of soil characteristics with forest cover.

Regarding the coefficient of discharge depletion over time $(\alpha)$, its pattern follows the same behavior, only in reverse direction, again excepting for spring L4. In this case, the size of the recharge area is also indicative of the size of the reservoir to be drained, noting that the larger it is the greater its inertia and therefore the smaller the variations over time.

The above consideration is confirmed by the values of $Q_{t} / Q_{0}$ ratio, the highest value occurring in spring $L 4(0.230)$, indicating that at the end of the recession period, the discharge rate is around $30 \%$ as much as the initial rate and is related to the lowest value of a $\left(0.0069\right.$ day $\left.^{-1}\right)$. Conversely, the lowest value of $Q_{\mathrm{t}}$. $\mathrm{Qt}_{0}$ ratio was found for spring $\mathrm{L} 3(0.008)$, indicating that at the end of the period the discharge rate is only $2.3 \%$ as much as the initial rate, indicating an aggravated recession of the aquifer, and is related to the highest value of $\alpha\left(0.0216\right.$ day $\left.^{-1}\right)$.
The runoff rates for the recession period is shown in Table 3, which were estimated based on the fitted equations, revealed good results when compared to Table 2 , since the highest deviation between the values is in the order of $13 \%$.

\section{CONCLUSIONS}

Results showed that drainage area size, soils characteristics and land cover did have an effect on the indicators of the streamflow regime for the studied springs.

Recharge area size had a positive influence on the indicators mean discharge and runoff volume and on the regulation of the streamflow (springs L4 and LI), noting that the spring under the smallest area of influence provided the lowest values for these indicators (spring L3).

The effect of forest cover (native and planted), associated with soils characteristics, was evidenced by the indicators runoff (in depth) and specific yield, independent of the recharge area size (springs L4 and L2).

The interaction between area size, soils characteristics and forest cover (native and planted) generated the best values for all indicators of the stremflow regime for the springs studied (spring L4).

\section{REFERENCES}

ANTONELI, V.; THOMAZ, E. L. Comparação de infiltração de água no solo mensurada em período seco e úmido, em diferentes usos da terra na bacia do arroio Boa Vista, Guamiranga, Paraná. Ambiência, Guarapuava, v. 5, p. 301-318, maio/ago. 2009.

BRANDÃO, V. S.; PRUSKI, F. P.; SILVA, D. D. Infiltração da água no solo. 3. ed. Viçosa, MG: UFV, 2006. 120 p.

CASTANY, G. Traité pretique des eaux souterraines. 2. ed. Paris: Dunod, 1967.66I p.

CORTINES, E. Funcionamento hidrológico de nascentes em microbacias instáveis, Barra de Guaratiba, RJ. 2008. 87 p. Dissertação (Mestrado em Ciências Ambientais e Florestais) Universidade Federal Rural do Rio de Janeiro, Seropédica, 2008.

COSTA, F. M.; BACELLAR, A. P. Caracterização hidrogeológica de aquíferos a partir do fluxo de base. Revista Brasileira de Recursos Hídricos, Ouro Preto, v. 15, n. 3, p. 173 I83, jul./set. 2010.

HILLEL, D. Soil and water: physical principles and process. New York: Academic, 1971. 288 p.

JUNQUEIRAJÚNIOR, J. A. Escoamento de nascentes associado à variabilidade espacial de atributos físicos e uso do solo em uma bacia hidrográfica de cabeceira do Rio Grande, MG. 2006. 84 p. Dissertação (Mestrado em Engenharia Agrícola) - Universidade Federal de Lavras, Lavras, 2006. 
MENEZES, M. D.; JUNQUEIRA JÚNIOR, J. A.; MELLO, C. R.; SILVA, A. M.; CURI, N.; MARQUES, J. J. Dinâmica hidrológica de duas nascentes, associada ao uso do solo, características pedológicas e atributos físico-hídricos na sub-bacia hidrográfica do Ribeirão Lavrinha, Serra da Mantiqueira, MG. Scientia Forestalis, Piracicaba, v. 37, n. 82, p. I75-184, jun. 2009.

PINHEIRO, A.; TEIXEIRA, L. P.; KAUFMANN, V. Capacidade de infiltração de água em solos sob diferentes usos e práticas de manejo agrícola. Ambi-Agua, Taubaté, v. 4, n. 2, p. I88-199, jul. 2009.

PINHEIRO, R. C.; TONELLO, K. C.; VALENTE, R. O. A. V.; MINGOTI, R.; SANTOS, I. P. Ocupação e caracterização hidrológica da microbacia do Córrego Ipaneminha, SorocabaSP. Irriga, Botucatu, v. I6, n. 3, p. 234-245, jul./set. 201 I.

PINTO, V. A. P.; BOTELHO, S. A.; DAVIDE, A. C.; FERREIRA, E. Estudo das nascentes da bacia hidrográfica do Ribeirão Santa Cruz, Lavras, MG. Scientia Forestalis, Piracicaba, n. 65, p. 197-206, jun. 2004.
PIRES, J. S. R.; SANTOS, J. E. dos. Bacias hidrográficas: integração entre meio ambiente e desenvolvimento. Ciência Hoje, São Carlos, v. 19, n. 10, p. 4-45, 1995.

SCHULER, A. E. Fluxos hidrológicos em microbacias com floresta e pastagem na Amazônia Oriental, Paragominas, Pará. 2003. II9 p. Tese (Doutorado em Ciências) - Centro de Energia Nuclear na Agricultura, Universidade de São Paulo, Piracicaba, 2003.

SILVA, L. A. Regime de escoamento e recarga subterrânea de nascentes na região do Alto Rio Grande, MG. 2009. I34 p. Dissertação (Mestrado em Engenharia Agrícola) Universidade Federal de Lavras, Lavras, 2009.

UNITED STATES ARMY CORPS OF ENGINEERS. Engineering and design: groundwater hydrology. Washington, 1999. $90 \mathrm{p}$.

YANAGI, S. M. N. Estruturação do banco de dados, análises e caracterização climática da região do Alto Rio Grande, MG. Lavras: FAPEMIG, 2008. 103 p. 
